\title{
Iraqi Personality in Light of Ali Al-Wardi's Works: A Critical Review
}

\author{
Hamied G. M. Al-Hashimia
}

\begin{abstract}
This paper sheds light on the Iraqi personality in light of writings of the Iraqi eminent sociologist Dr. Ali Al-Wardi and gives a critical review to his main findings and hypotheses. Al-Wardi was the main person who established the first department of sociology in Iraq and the spiritual father or the real father of sociology in the country. He wrote prestigious works about the Iraqi society including some hypotheses focusing on the Iraqi personality, such as the dual personality and social dissonance. These findings and hypotheses are not above criticism of course. The method we depend on here is the content analysis methodology. The paper consists of seven parts; part one is the introduction which includes a short glimpse on the subject and Al-Wardi's methodology. Part two deals with Al-Wardi and studying Iraqi personality. Part three, discusses the dual personality, and part four, the social dissonance. Part five, exposures tackling the problem where Al-Wardi suggests some points. Part six deals with the discussion. Finally, there is a conclusion under the part seven.
\end{abstract}

\section{Keywords}

Iraq personality, Ali Al-Wardi, dual personality, social inconsistency, tribal values

It is six decades since Ali Al-Wardi presented his first public lecture and published his first book (The Personality of the Iraqi Individual: A Study of Iraqi Personality in Light of New Psychological Science). The book has created controversy since it was published in 1951. Three years later, he published his second book titled Preachers of the Sultans which has similar interest in common. His opinions have stirred up the stagnant water in intellectual circles.

His works, approach in studying society and hypotheses and generalizations on the Iraqi and Arab personality have become very common either inside the Arab world or abroad. Some of his books have been translated into different languages such as English, German, Spanish, Polish, and Persian. Therefore, it is very important to be reviewed and criticized from time to time.

Methodologically, Al-Wardi depended as he said on a method that makes a compromise between Ibn Khaldoun's theory and modern theories, which are divided into Marxist and idealistic. He believed that a scholar has to take advantage of all ideas that benefit sociological development in the world. Al-Wardi also adopted the historical approach in sociology unlike other sociologists who preferred the statistical approach. He adopted the sociological aspects in studying history or in his interpretation of behaviour in Iraqi society such as dual personality or social dissonance. Al-Wardi also stressed two points: objectivity and neutrality in all his writings. He simply rejected statistical approach and the consequent use of

aInternational Colleges of Islamic Sciences, UK

\section{Correspondent Author:}

Hamied G. M. Al-Hashimi, 17 Leighton Close, Edgware HA8 5SE, UK 
opinion surveys and interviews, saying that the Iraqi society is not like the American society where researchers are able to knock doors and ask housewives any questions they might have on their minds (Al-Hashimi 2013: 251-259).

\section{AL-WARDI AND STUDYING IRAQI PERSONALITY}

Personality is a psychological composite of a variety of traits, or characteristics, which tend to be in accord with a prevailing dominant societal culture. Each human being has a personality. It differentiates him from others on the ability to respond to his prevailing culture. Human experiences affect personality, and personality in turn influences the level type of experience (Al-Wardi 2008: 59).

Iraqi personality in general is not different from others, but there are some (local) characteristics. Generally speaking, Al-Wardi is focused on the Bedouin values and its effect on the day life of the Iraqi society. He sees that most of the Iraqi recent inhabitants came from a Bedouin background or emigrated from the Sahara of Arab Peninsula. Therefore, he focused on this issue and its consequences on culture and personality.

Al-Wardi states that when nomadic tribes leave the desert and settle in rural areas, they confront harsh circumstances with which they are not familiar. They face psychological as well as social pressure in their adjustment and their ability to preserve the old nomadic values. Some deviation from those values is expected which can lead to personality conflict (Al-Wardi 2008: 67).

We are focusing on this issue by reviewing the related works of Al-Wardi.

In his first book, he confirms that Iraqi society like any other society has some special social characteristics that contribute to forming the personality of its individuals. In fact, the author has suffered to diagnose these characteristics that form the
Iraqi personality. Yes, after a hard study, the author could conclude his findings in this issue. In this critical stage of our history, we are in urgent need to understand the psychology of Iraqi society, and how the individual personality is formed, so we can wisely lead it to the progress. We should admit that there is no benefit from turning the blind eye on our negative traits. Each nation has some negative characteristics. In fact, there is no ideal nation (Al-Wardi 2000: 45).

We exposure here to the main two findings of Al-Wardi: dual personality and social dissonance.

\section{DUAL PERSONALITY}

It is known as split personality and ambivalence. Ambivalence can be defined as the following: It is the coexistence in one person of opposing emotions or attitudes. Sigmund Freud often refers to the individual oscillating between love and hate for the same object or person. In sociology, the dual consciousness thesis posits a subordinate class which holds apparently inconsistent beliefs or values, resulting in an ambivalent attitude to some of the central institutions in society (Marshal 1998: 18).

Al-Wardi made it clear that dual/split personality is a social phenomenon that appears in many societies where a cultural conflict exists. Dual personality, as the author sees, is in the subconscious often. A dual man may get angry when someone alerts him/her to the contradiction that appears in two situations in his/her life. This duality arises as a result of becoming fewer than two different systems of social values. There you see he/she assumes the right certain personality at times and then turns into a second character at other times.

As an illustration, Al-Wardi presents the example of a young Iraqi who wishes to choose his own wife, just like an enlightened Western man, and to exchange love letters with her... but when he hears that some other man has similar relations with his sister or 
cousin, he immediately turns into a "Bedouin" and murders his beloved sister and her lover.

Al-Wardi believed that the Iraqi individual suffers from dual personality, which can be treated to ancient history, especially with the advent of Islam. He asserted that the collective Iraqi character was "a double personality" of law-abiding urban sophistication and a Bedouin desert code that condoned looting. So, it is a conflict between the Bedouin values that have been passed down through the generations and the cultural values that the Iraqi society has acquired.

Al-Wardi ensures that every person wants to acquire high status and admiration from the people around him. What constitutes high status and admiration is, however, in different societies, that every person learns how to acquire them according to his own society where he grows up. Children who grow up in Iraqi neighborhoods learn that being an aggressor, being physically strong (and proving it by beating other children up), and stealing are the things that get them high status among their peers. When they grow up, these learned values do not go away; they became ingrained in them; but at the same time, their exposure to preachers increases. They get lectured about the importance of patience, humbleness, and being just; and things that if they practiced in their everyday life, they will get beaten up and looked down upon. This made Iraqis in general advocate the best personality traits in their talks but practice the exact opposite.

Al-Wardi cites this interesting example to clarify dual personality: A tribesman has a double personality. $\mathrm{He}$ is valiant and has met with other tribesmen. $\mathrm{He}$ is very emotional and keen on taking revenge. However, this same tribesman becomes completely different person when he sees government income taxman on influential figures. He becomes quite submissive, well prepared to accept insults and even beating without having the slightest desire to hate or revolt (Al-Wardi 1996: 86). Other examples about the dual personality include bribery, pretending to respect woman, and belief in woman's right as well as human right.

Al-Wardi gives another example to support his point. He describes Iraqis as people who are known for their love of argument and debate, which is a good trait in general, but if taken too far (as in Iraqi society), it makes people too critical of others. It teaches the person to require perfection and idealism from others even while being unable to reach this state himself.

A number of reasons can be said beside what mentioned above to be lying behind this phenomenon such as the inclination of Moslem scholars to keep arguing which resulted in the emergence of several Islamic and philosophical groups and doctrines, the long political conflict and the impact of Bedouin values on people whether they live in cities or in countryside (Al-Hashimi 2013: 251-259).

Likewise, Bedouin values of glorify racism, vengeance, looting, killing women to wash away shame and so forth, while Islam condemns all those and considers them banned; nevertheless, those values were common in the Ottoman period as many people glorified the man who shakes the ground when he walks and who robs houses at night out of manhood, describing him as a "lion", "nightman", or "tribe's pride". Al-Wardi's theory clarifies that Bedouin culture is characterized by three elements: (1) tribalism; (2) raiding; and (3) chivalry. Each of these elements is defined by the concept of "al-taghalub" or predominance. The Bedouin individual seeks to win over or predominate others by the force of his tribe, his personal strength, and his sense of superiority (Al-Hashimi 2014).

Moreover, Al-Wardi states that Iraq has almost been ruled by cruel rulers who did not care much for the people and looked down on them. So the people had always hated their rulers and "respected" them out of fear. This created a psychological issue in the Iraqis: They come to see a respectable person as someone who looks down on them and only talks to them with an air of disgust; and if that person humbles himself, 
he would lose his high status among them and they will walk all over him. So for Iraqis, respect became synonymous with cruelty, hubris, and arrogance.

\section{SOCIAL DISSONANCE}

Social dissonance is the second hypothesis of Al-Wardi beside the first one (dual personality). In Al-Wardi's concept, it means: the violent conflict or contradiction between the old and the new, resulting from the rapid changes in life, especially the technological progress and the resulting changes from the paradoxes of this behavior. While Merriam Webster Dictionary defines dissonance as the following (Merriam Webster Dictionary 2014):

(1) Lack of agreement; especially: inconsistency between the beliefs one holds or between one's actions and one's beliefs;

(2) An instance of such inconsistency or disagreement;

(3) A mingling of discordant sounds; especially: a clashing or unresolved musical interval or chord.

Al-Wardi compares the nature of the change in the current era with the last ages of technology, where he diagnoses that first one causes confusion and contradictory behavior, due to the rapid rhythm. While in the second, it is a result of the slow changes, where man can gradually adjust to it. Therefore, the confusion and contradictory behavior disappear.

In a nutshell, social dissonance is a social and moral disorder that reflects the asymmetry in the evolution of society. It may be resulted from slowness in the rate of change of one part of a culture in relation to another part, resulting in maladjustment within society, as from the failure of the nonmaterial culture to keep abreast of developments in the material culture. And that is what William Ogburn said in what he called the "Cultural Lag" (Dictionary.com 2014).

Al-Wardi himself admitted that saying:

I use this concept as a translation to the concept of
(Cultural Lag) that created by William Ogburn, since I used it for the first time in my book (A Study in the Nature of the Iraqi Society, 1965), and I consulted the Iraqi Academy of Sciences hoping to get an answer whether positive or negative, but unfortunately there was no answer. (Al-Shamaa 2004)

Al-Wardi gives some practical examples of the social dissonance like (Al-Wardi 1996: 50-51):

The situation of women in Iraq; where he says "they are suffering a lot from this social disorder. Men as well are suffering but less than women". He states that Iraqi woman is caught in a dilemma between two contradictory trends: the stream of modern civilization that drives her forward on one hand, and on the other, the tide of the old values, which have been withdrawn towards the back.

Sexual harassment is another problem facing women in Iraq. It is very common at this period as Al-Wardi states. He sees this phenomenon resulted from the raising of social dissonance that the Iraqi woman particularly is suffering from. Recently, man was not able to harass women, because of the gender segregation in the public space.

\section{TACKLING THE PROBLEM}

Al-Wardi suggests his vision for tackling this social disorder, by the following (Al-Wardi 2001: 74):

First: Liberate women from the veil (hijab), educate and merge them in man's world, in order to unite the values and attitudes towards men and women, so they can understand and achieve their goals and aspiration.

Second: Reduce the great difference between the local dialect and standard Arabic language. Speak as you present and preach and preach as you speak. Leave what Sibawayh, Neftawyh, Al-Hariri, and Al-Hamathani created of moonshine, void and useless grammars.

Third: Prepare children's playgrounds and kindergartens where they enjoy good life under the 
supervision of qualified instructors. Teach them that the force that rules the world today is not the power of an individual person versus another one, or fencing. It is the power of science, industry, and order. Who fails in this, he will fail in the realm of life, and despite his claim to the right and demonstration ideals.

\section{DISCUSSION}

Despite the importance of Al-Wardi's opinions, we may not agree on some of these opinions as he generalized on the Iraqi society in some judgements such as his saying: "Perhaps the Iraqi individual of more people passionate in ideals, but at the same time, the more people deviant by"; or elsewhere in "clear conflict nomadic civilization and most pronounced manifestations in Iraq" (Al-Wardi 2000: 298).

In another judgment, he says "Iraqi person is the most one suffering from dual personality than others from the Arab countries".

In this and many like this judgement in most of his works, it seems that Al-Wardi compares the Iraqi society with other Arab societies. But unfortunately, Al-Wardi had not enough ideas about those societies. In the author's opinion, if Al-Wardi had a good idea about them, then he would change at least his examples. Likewise, he would change his judgements as well as increase mindedness, and accordingly, we could get many shiny works by Al-Wardi than we are fascinated by now. We do not want to be biased to our society or defend it, but we would like to discuss what can be considered a "stereotype" rather than a scientific finding. In few words, we do not agree that the Iraqi society/individual is more suffering from the dual personality than other Arab societies.

Basically, dual personality arises among people who play more than one role in life whether in social or public life, and formal activities; more precisely, people who live in two different social atmospheres and those facing many taboos (prohibitions). These types of social problems increase among the communities where there is a high domination by radical, social, and religious values, totalitarianism, puritanical, political, and dictatorship rules. In such examples and as a comparison with Iraqi society, we can refer to some neighboring societies, e.g. Arab Gulf States, Jordan, Syria or Egypt, Libya, and other North African societies. We think these societies have a lot of such characteristics. Until recently, Iraqi society was more open and tolerant.

It is likely that Al-Wardi did not have communication with other communities, where most of his models are often to compare with Lebanese, Syrian, and Egyptian societies. The possibility that the period in which he wrote his books had yet to see the social and political entities well-defined for him, especially in the form of an independent state, where most of the Gulf countries became independent at the beginning of 1970s, with the exception of Saudi Arabia (1930), and Kuwait (1962). The countries of the Arab Maghreb became independent in the mid-fifties of the last century.

With regard to the second hypothesis (social dissonance), we see this is very similar to the first one (dual personality), and sometimes you cannot recognize during the analysis between them, especially when he focuses on the intermingling of Bedouin and urban values as a main reason to the most social disorders.

\section{CONCLUSIONS}

According to the key findings of Al-Wardi's studies, we can conclude that the Iraqi personality was the central topic of those studies and his sociological perspective revolves around the intermingling and conflict between the Bedouin (nomadic) culture and the urban cities. As a result of that, he formed his two hypotheses: "dual personality" and "social dissonance" which he wanted to generalize on all Arab societies.

Moreover, Al-Wardi formed most of his analyses depending on the lifestyle of the Ottoman period in 
Iraq and especially Baghdad city. When we look at the methodological principles he governed his work, Al-Wardi seemed to lack such principles. The samples he had collected depended only on his knowledge of his society and the people who lived in it. $\mathrm{He}$ depended on various sources and people in his studies, but his conclusions and generalisations on big social units were based on his study of smaller social units.

Dual personality and social dissonance in general are two faces of one currency as they said, rather than two different issues. We definitely agree with Al-Wardi that Iraqi society is one of the most societies suffering from this disorder but not the unique or first one.

\section{References}

Al-Hashimi, H. 2013. "Iraqi Sociology and Al Wardi's Contributions." Contemporary Arab Affairs 6(2):251-260.

- 2014. The Question of Violence in the Iraqi Personality. Retrieved (http://archive.frontpagemag.com/readArticle.asp $\mathrm{x}$ ?ARTID=4065).

Al-Shamaa, S. 2004. "Al Wardi Yunaqish Baadh Almofakkirin Alarduneen: Kul Almujtamaat Alarabiya Tuani min Altanashuz Alijtimaai" (Al Wardi Discusses Some Jordanian Thinkers: All Arab Societies Are Suffering From the Social Dissonance). Assout AL Alakher Mag. 24:11-15.

Al-Wardi, A. 1996. "Foreword: Albazzaz, Saad." In Filtabia'at Albashariah (In the Human Nature). London: Kufan House. . 2000. Lamahat Ijtimaiyah Min Tarikh Aliraq Alhadith
(Social Glimpses From the Iraqi Modern History). Vol. 1. Qum: Intisharat Al-Maktaba Al-Haidariya.

—. 2001. Shakhsiyat Alfard Aliraqi: Dirasah Fi Dhooa Ilm Alnafs Alhadith (Personality of the Iraqi Individual: A Study of Iraqi Personality in Light of Psychology). London: Layla House for Publication.

- 2008. Understanding Iraq: Society, Culture and Personality. Translated with a foreword by F. Baali. New York: The Edwin Mellen Press Ltd.

Dictionary.com. 2014. Cultural Lag. Retrieved (http://www. dictionary.com/browse/cultural-lag).

Marshal, G. 1998. Oxford Dictionary of Sociology. 2nd ed. New York: Oxford University Press.

Merriam Webster Dictionary. 2014. Dissonance. Retrieved (http://www.merriam-webster.com/dictionary/dissonance).

\section{Bio}

Hamied G. M. Al-Hashimi, Ph.D. in sociology, professor of sociology at International Colleges of Islamic Sciences (ICIS), London, fieldwork social researcher at NatCen: Social Research, London, and visiting professor at Al Qadisiya University in Iraq, assistant professor of sociology at University of Europe, Rotterdam, the Netherlands (2001-2007) and a staff member of the Department of Sociology, College of Arts in Zwara, Libya (1994-1998), author of five published books on: "Iraqi Armenians: History, Culture \& Identity", "Gypsies in Iraq", "Arab Immigrants in the Netherlands", "Towards Forming a Theoretical Framework on Social Integration", and "Iraqi Sociologist Ali Al Wardi's Methodology in Studying Iraqi and Arab Societies"; research fields: immigration, social integration, minorities, identity, Iraq \& Middle East. 